\title{
Implementation of PBL to enhance the soft skills of engineering students
}

\author{
Hairuzila Idrus ${ }^{1, *}$, and Muhammad Ridhuan Tony Lim Abdullah ${ }^{1}$ \\ ${ }^{1}$ Department of Management \& Humanities, Universiti Teknologi PETRONAS, Perak, Malaysia.
}

\begin{abstract}
The objective of this paper is to look into the implementation of PBL in the teaching of engineering courses to enhance the students' ability in soft skills. The importance of soft skills has been acknowledged in most occupations and many organizations make selection and performance evaluation decisions based in part on employees' soft skills. Problem Based Learning (PBL) is a pedagogical approach that has the potential to harness students' ability in soft skills. Thus, this study looks into the implementation of PBL at a private university in Malaysia based on the lecturers' industry experience, teaching experience and the engineering program they are in. A set of questionnaire is given to 90 lecturers teaching engineering courses to gauge the extent to which PBL is employed by the lecturers. An independent-samples t-test was conducted to compare the mean scores of the two groups which were the lecturers with industry experience and the ones without industry experience on the teaching approaches employed by them. A one-way between-groups analysis of variance (ANOVA) is conducted to explore the teaching methods employed by lecturers of different years of teaching experience and engineering programs. The analysis showed that $77.7 \%$ of the lecturers prefer to employ problem-based learning (PBL) in their teaching of engineering courses. The results also revealed that the preference stayed constant in relation to the lecturers' experience with the industry, years of teaching experience and the engineering program they are in. Thus, this illustrates that the lecturers prefer to employ student-cantered approach which lead to producing students with better soft skills like critical thinking. Similar patterns appeared in relations to the comparison by years of teaching experience, where lecturers with 6-10 years of teaching experience highly employed PBL. On the comparison by engineering program, lecturers from Chemical engineering (CE) program show the most frequently usage of PBL. The study also found that the soft skills that could be enhanced through PBL are critical thinking and problem solving skills, communication skills and teamwork skills.
\end{abstract}

\section{Introduction}

The main objectives of education are the holistic development of character and capabilities, the acquisition of specific skills, the realization of intellectual, physical and spiritual potential, and the training of human capital. Therefore, as noted by Hazadiah, et al. (2008), the Malaysian Ministry of Higher Education has produced a profile of the desired human capital based on three principles: knowledge, personal, and interpersonal attributes.

\footnotetext{
* Corresponding author: hairuzi@utp.edu.my
} 
Higher education institutions must ensure that their teaching resources are in place, revamp programs and systems, and re-engineer learning processes to develop these attributes in all students. These initiatives signify the importance of teaching and learning in this transformation of education system in Malaysia.

In today's society and in the future soft skills are becoming more important especially baseline soft skills for instance communication and continuous learning among others. The importance of soft skills has been acknowledged in most occupations and many organizations make selection and performance evaluation decisions based in part on employees' soft skills. During economic uncertainties, graduates have the more reason to improve themselves in the soft skill areas and be ready for an upswing in the job market. This was because there were still job openings for entry-level positions for fresh graduates but the competition was tough, thus graduates who were equipped with substantial skills, knowledge and the right attitude to survive in any crisis would have high chances to get the jobs. This implied that graduates were able to secure jobs if they possessed good soft skills (Beagon \& Niall, 2015; Hamidah, Yuriani \& Palupi, 2016; Othman et al., 2017).

PBL is a learner focused educational approach where the student extends previous knowledge to new problems through self-directed reflection, research and practice in solving a problem (Khairiyah et al., 2007). PBL was adopted by many engineering programs as an approach to help students learn the skills required by the employers and to address many of the concerns that engineering graduates are lacking in of soft skills.

The objectives of this paper are first, to find out to what extend PBL is being implemented by the lecturers at this university in their teaching based on their experience with the industry, years of teaching and the engineering program they are in. And second to find out the soft skills that could be enhanced through the implementation of PBL in teaching engineering courses from the lecturers' perspectives.

\section{Methodology}

The respondents of this study were lecturers from four engineering programs, namely Mechanical Engineering (ME), Chemical Engineering (CE), Civil Engineering (CV) and Electrical and Electronics Engineering (EE), at a private university. The total number of lecturers from these program is 125 which consist of: ME 34, CV 26, EE 36 and CE 29. Since the number is not large, all of them were taken as the respondents in the study. Out of 125 questionnaires sent through the email and by hand, 90 lecturers responded. The 90 completed questionnaires that are used in the study represent a return rate of 72 percent. Table 1 below summarizes the lecturers' demographic information. 
Table 1. Lecturers' demographic information

\begin{tabular}{|l|c|c|}
\hline Demographic items & n & \% \\
\hline Gender & 71 & 78.9 \\
Male & 19 & 21.1 \\
\hline Female & 62 & 68.9 \\
Educational achievement & 28 & 31.1 \\
Master & & \\
\hline Engineering program & 24 & 26.7 \\
EE & 24 & 26.7 \\
ME & 21 & 23.3 \\
CE & 21 & 23.3 \\
CV & 30 & 33.3 \\
\hline Teaching experience & 20 & 22.2 \\
$1-5$ years & 18 & 20.0 \\
$6-10$ years & 6 & 6.7 \\
$11-15$ years & 16 & 17.8 \\
$16-20$ years & & \\
More than 20 years & 60 & 66.7 \\
\hline Industry experience & 30 & 33.3 \\
\hline Yes & & \\
No & & \\
\hline
\end{tabular}

The set of questionnaire for the lecturers focuses more on teaching approaches that the respondents employ in their teaching of technical courses. The items are generated based on the literature review carried out by the authors on the approaches taken to integrate soft skills in the teaching of technical courses in order to enhance the students' ability in soft skills. The teaching approaches included in the questionnaire are problem based learning, project oriented problem based learning, cooperative learning, teacher centred approach, project based approach. This section also asks on the understanding of the lecturers on the importance of soft skills by stating statements regarding benefits of soft skills to technical students, common perception pertaining to soft skills and the ability of students in soft skills.

\section{Results and findings}

This section is divided into 3 sections for discussion which are the respondents' teaching approaches, industry experience, teaching experience and engineering program.

\subsection{Teaching approaches}

This particular section assessed the teaching approaches employed by the lecturers in integrating soft skills in their teaching of technical courses. In the questionnaire, the authors placed both the traditional and non-traditional teaching methods because they did not want to assume that only non-traditional teaching methods can be used to integrate soft skills. The analysis showed that the teaching approach employed by the majority, which was about 69 (77.7 percent) of the lecturers was problem-based learning (PBL), followed by project-oriented problem-based learning approach (POPBL) employed by about 57 lecturers or 63.3 percent, project-based learning (PjBL) 60 percent or about 54 lecturers, cooperative learning was employed by about 53 or 58.9 percent and lastly the traditional approach, teacher-centred approach employed by 45.6 percent or 41 of the lecturers. 
The overview revealed that the lecturers seemed to have a greater preference for problembased learning, project oriented problem-based learning, project-based learning and cooperative learning, which were more student-centred as opposed to teacher-centred approach, a more traditional approach.

\subsection{Industry experience}

The reason why this matter is looked into was to find out if the lecturers' experience working with the industry affects their teaching approach. This was because the people from the industry were the ones who pointed out that many graduates are lacking in their soft skills, as such it would be interesting to find out whether the teaching approaches by those academics who were in the industry before were any different from those who were purely from academic and had no experience working with the industry. The numbers of respondents for the lecturers with industry experience and without industry experience were 60 and 30, respectively. The respondents were required to indicate their level of frequency in employing the teaching approaches listed in the questionnaire. They indicated their frequency in employing each teaching approach in a five-point Likert scales from ' 1 ' meaning never use the teaching approach, to ' 5 ' meaning always use the teaching approach. The interpretation of the mean score was adapted from Landell (1997) on the frequency of using the teaching methods as in Table 2 below:

Table 2. Interpretation of mean score

\begin{tabular}{|c|c|}
\hline Range of mean score & Frequency \\
\hline $1.00-2.33$ & Low \\
\hline $2.34-3.67$ & Average \\
\hline $3.68-5.00$ & High \\
\hline
\end{tabular}

Based on their responses, the data were analyzed and the mean score of each teaching approach is shown in the table below. Table 3 below presents the summary of means for the teaching approaches employed by the lecturers in their teaching by making comparison between the mean score of the lecturers with industry experience to the ones without industry experience.

Table 3. Summary of mean score for teaching approach

\begin{tabular}{|c|c|c|c|c|c|}
\hline $\begin{array}{c}\text { Teaching } \\
\text { approach }\end{array}$ & $\begin{array}{c}\text { Industry } \\
\text { experience }\end{array}$ & N & $\begin{array}{c}\text { Mean } \\
\text { score }\end{array}$ & $\begin{array}{c}\text { Std. } \\
\text { Dev. }\end{array}$ & Frequency \\
\hline PBL & Yes & 60 & 4.10 & 0.86 & High \\
& No & 30 & 3.97 & 0.96 & High \\
POPBL & Yes & 60 & 3.85 & 1.04 & High \\
& No & 30 & 3.53 & 1.36 & Average \\
& Yes & 60 & 3.82 & 0.91 & High \\
PjBL & No & 30 & 3.53 & 1.22 & Average \\
& Yes & 60 & 3.67 & 0.99 & Average \\
CL & No & 30 & 3.83 & 1.05 & High \\
& Yes & 60 & 3.52 & 1.10 & Average \\
TCA & No & 30 & 3.67 & 0.96 & Average \\
\hline
\end{tabular}


From Table 3 above it was evident that most items have a mean score ranging between 3.53 and 4.10 implying that the lecturers no matter whether they have the industry experience or not did employ the stated teaching approaches. However, the frequency of using teaching approaches like POPBL, PBL and CL differed where the lecturers with industry experience used POPBL and PBL more regularly than lecturers without industry experience. In addition, the lecturers without industry experience frequently use CL as compared to the lecturers with industry approach. Thus, the analysis revealed that there were differences on the frequency in the teaching approaches employed by lecturers with industry experience and without the experience. Both groups frequently employed PBL in their teaching.

\subsection{Teaching experience}

The lecturers were divided into five groups which were those with teaching experience of 1 -5 years, $6-10$ years, $11-15$ years, $16-20$ years and more than 20 years. The realization on the importance of soft skills started in the 1980s, which was about 30 years ago. Thus, the aim was to find out if the years of teaching experience of the lecturers have any influence in the teaching approach that they employed in integrating soft skills in their teaching. This somehow could indicate the awareness of the lecturers on the teaching approaches that could be employed to enhance students' soft skills ability. The result tabulated in Table 4 represents the mean scores for the five different groups of lecturers on the teaching approaches addressed in this study. The following results are observed. 
Table 4. Mean score

\begin{tabular}{|c|c|c|c|c|c|}
\hline $\begin{array}{l}\text { Teaching } \\
\text { approach }\end{array}$ & $\begin{array}{c}\text { Teaching } \\
\text { Experience }\end{array}$ & $\mathbf{N}$ & Mean & $\begin{array}{l}\text { Std. } \\
\text { Dev. }\end{array}$ & Frequency \\
\hline PBL & $\begin{array}{c}1-5 \text { years } \\
6-10 \text { years } \\
11-15 \text { years } \\
16-20 \text { years } \\
>20 \text { years } \\
\text { Total }\end{array}$ & $\begin{array}{c}30 \\
20 \\
18 \\
6 \\
16 \\
90\end{array}$ & $\begin{array}{l}3.97 \\
4.60 \\
3.67 \\
3.50 \\
4.19 \\
4.05\end{array}$ & $\begin{array}{l}.85 \\
.68 \\
1.08 \\
.84 \\
.65 \\
.89\end{array}$ & $\begin{array}{c}\text { High } \\
\text { High } \\
\text { High } \\
\text { Average } \\
\text { High } \\
\text { High }\end{array}$ \\
\hline $\mathrm{CL}$ & $\begin{array}{c}1-5 \text { years } \\
6-10 \text { years } \\
11-15 \text { years } \\
16-20 \text { years } \\
>20 \text { years } \\
\text { Total }\end{array}$ & $\begin{array}{c}30 \\
20 \\
18 \\
6 \\
16 \\
90\end{array}$ & $\begin{array}{l}3.53 \\
4.40 \\
3.72 \\
3.16 \\
3.43 \\
3.72 \\
\end{array}$ & $\begin{array}{l}1.00 \\
.82 \\
.96 \\
.98 \\
.96 \\
1.00\end{array}$ & $\begin{array}{c}\text { Average } \\
\text { High } \\
\text { High } \\
\text { Average } \\
\text { Average } \\
\text { High }\end{array}$ \\
\hline $\mathrm{TC}$ & $\begin{array}{c}1-5 \text { years } \\
6-10 \text { years } \\
11-15 \text { years } \\
16-20 \text { years } \\
>20 \text { years } \\
\text { Total }\end{array}$ & $\begin{array}{c}30 \\
20 \\
18 \\
6 \\
16 \\
90\end{array}$ & $\begin{array}{l}3.43 \\
3.35 \\
3.78 \\
4.00 \\
3.69 \\
3.57\end{array}$ & $\begin{array}{c}.89 \\
.69 \\
1.06 \\
.89 \\
1.48 \\
1.50\end{array}$ & $\begin{array}{c}\text { Average } \\
\text { Average } \\
\text { High } \\
\text { High } \\
\text { High } \\
\text { High }\end{array}$ \\
\hline PjBL & $\begin{array}{c}1-5 \text { years } \\
6-10 \text { years } \\
11-15 \text { years } \\
16-20 \text { years } \\
>20 \text { years } \\
\text { Total }\end{array}$ & $\begin{array}{c}30 \\
20 \\
18 \\
6 \\
16 \\
90\end{array}$ & $\begin{array}{l}3.80 \\
4.45 \\
3.33 \\
2.67 \\
3.50 \\
3.72\end{array}$ & $\begin{array}{l}.87 \\
.69 \\
.97 \\
.82 \\
1.21 \\
1.03\end{array}$ & $\begin{array}{c}\text { High } \\
\text { High } \\
\text { Average } \\
\text { Average } \\
\text { Average } \\
\text { High }\end{array}$ \\
\hline POPBL & $\begin{array}{c}1-5 \text { years } \\
6-10 \text { years } \\
11-15 \text { years } \\
16-20 \text { years } \\
>20 \text { years } \\
\text { Total }\end{array}$ & $\begin{array}{c}30 \\
20 \\
18 \\
6 \\
16 \\
90\end{array}$ & $\begin{array}{l}4.03 \\
4.20 \\
3.23 \\
2.67 \\
3.56 \\
3.74\end{array}$ & $\begin{array}{c}.81 \\
1.28 \\
1.02 \\
.82 \\
1.41 \\
1.16\end{array}$ & $\begin{array}{c}\text { High } \\
\text { High } \\
\text { Average } \\
\text { Average } \\
\text { Average } \\
\text { High }\end{array}$ \\
\hline
\end{tabular}

With reference to Table 4 above, the analysis showed that the mean score for PBL for lecturers with 1-5, 6-10, 11-15, 16-20 and more than 20 years of experience ranged between 3.50 and 4.60 , which was quite a high frequency.

The analyses have also shown that the group of lecturers with $16-20$ years of teaching experience seem to obtain average mean scores for all four student-centred learning approaches as the mean scores were 3.50 for PBL, 3.16 for CL, 2.67 for PjBL and 2.67 for POPBL, but high frequency for teacher-centred approach with a mean score of 4.00 which signifies this group frequently employed the traditional approach.

Based on the mean scores, the results revealed that lecturers with teaching experience of 1-5 years and $6-10$ years most of the time employed more of the student-centred teaching approaches like PBL with mean scores of 3.97 and 4.60 respectively, CL mean scores of 3.53 and 4.40, PBA with mean scores 3.80 and 4.45 and POPBL with mean scores of 4.03, 4.20 , while the lecturers with $11-15$ years, 16 - 20 years, more than 20 years teaching experience employed more of the teacher-centred approach with mean scores of 3.78, 4.00, 
and 3.68, respectively. To determine the statistically significant difference in the comparison between the lecturers of different years of teaching experience, a one-way between-groups analysis of variance (ANOVA) was used since the independent sample $\mathrm{t}$ test was not applicable.

A one-way between-groups analysis of variance was conducted to explore the teaching methods employed by lecturers of different years of teaching experience in integrating soft skills in their teaching of technical courses, as measured by the questionnaire. Subjects were divided into five groups based on their years of teaching experience, namely, $1-5$ years, $6-10$ years, $11-15$ years, $16-20$ years and more than 20 years. The results of ANOVA test are summarized in Table 5 below.

Table 5. General mean scores, standard deviation and p-value of respondents' teaching approach based on years of teaching experience using one-way

ANOVA

\begin{tabular}{|c|c|c|c|c|c|}
\hline $\begin{array}{l}\text { Teaching } \\
\text { approach }\end{array}$ & $\begin{array}{c}\text { Teaching } \\
\text { Experience }\end{array}$ & Mean & $\mathbf{N}$ & $\begin{array}{l}\text { Std. } \\
\text { Dev. }\end{array}$ & p-value \\
\hline PBL & $\begin{array}{c}1-5 \text { years } \\
6-10 \text { years } \\
11-15 \text { years } \\
16-20 \text { years } \\
>20 \text { years } \\
\text { Total }\end{array}$ & $\begin{array}{l}3.97 \\
4.60 \\
3.67 \\
3.50 \\
4.19 \\
4.05\end{array}$ & $\begin{array}{c}30 \\
20 \\
18 \\
6 \\
16 \\
90\end{array}$ & $\begin{array}{l}.85 \\
.68 \\
1.08 \\
.84 \\
.65 \\
.89\end{array}$ & $.006^{*}$ \\
\hline $\mathrm{CL}$ & $\begin{array}{c}1-5 \text { years } \\
6-10 \text { years } \\
11-15 \text { years } \\
16-20 \text { years } \\
>20 \text { years } \\
\text { Total }\end{array}$ & $\begin{array}{l}3.53 \\
4.40 \\
3.72 \\
3.16 \\
3.43 \\
3.72 \\
\end{array}$ & $\begin{array}{c}30 \\
20 \\
18 \\
6 \\
16 \\
90\end{array}$ & $\begin{array}{l}1.00 \\
.82 \\
.96 \\
.98 \\
.96 \\
1.00\end{array}$ & $.008^{*}$ \\
\hline $\mathrm{TC}$ & $\begin{array}{c}1-5 \text { years } \\
6-10 \text { years } \\
11-15 \text { years } \\
16-20 \text { years } \\
>20 \text { years } \\
\text { Total }\end{array}$ & $\begin{array}{l}3.43 \\
3.35 \\
3.78 \\
4.00 \\
3.69 \\
3.57\end{array}$ & $\begin{array}{c}30 \\
20 \\
18 \\
6 \\
16 \\
90\end{array}$ & $\begin{array}{c}.89 \\
.69 \\
1.06 \\
.89 \\
1.48 \\
1.50\end{array}$ & .517 \\
\hline PjBL & $\begin{array}{c}1-5 \text { years } \\
6-10 \text { years } \\
11-15 \text { years } \\
16-20 \text { years } \\
>20 \text { years } \\
\text { Total }\end{array}$ & $\begin{array}{l}3.80 \\
4.45 \\
3.33 \\
2.67 \\
3.50 \\
3.72\end{array}$ & $\begin{array}{c}30 \\
20 \\
18 \\
6 \\
16 \\
90\end{array}$ & $\begin{array}{l}.87 \\
.69 \\
.97 \\
.82 \\
1.21 \\
1.03\end{array}$ & $.000^{*}$ \\
\hline POPBL & $\begin{array}{c}1-5 \text { years } \\
6-10 \text { years } \\
11-15 \text { years } \\
16-20 \text { years } \\
>20 \text { years } \\
\text { Total }\end{array}$ & $\begin{array}{l}4.03 \\
4.20 \\
3.23 \\
2.67 \\
3.56 \\
3.74\end{array}$ & $\begin{array}{c}30 \\
20 \\
18 \\
6 \\
16 \\
90\end{array}$ & $\begin{array}{c}.81 \\
1.28 \\
1.02 \\
.82 \\
1.41 \\
1.16\end{array}$ & $.007 *$ \\
\hline
\end{tabular}


The one-way ANOVA test was used through the manipulation of the data to test for a significant difference. The results of the one-way ANOVA in Table 5 indicated that there were significant differences (p-values) in all the teaching approaches with regard to the lecturers' years of teaching experience except for Teacher-centred Approach. The result found that there was a statistically significant difference at the $\mathrm{p}$ less than $0.05(\mathrm{p}<.05)$ level in the mean scores of teaching approaches employed by the lecturers with regard to PBL, $\mathrm{CL}, \mathrm{PjBL}$ and POPBL in which the p-values were .006, .008, 0.000 and 0.007 , respectively.

In order to find out where these differences laid, post-hoc test was used. The ANOVA for PBL revealed that there was a statistically significant difference in the means of the lecturers' years of teaching experience for PBL. With the p-value of 0.006, the result of the Tukey HSD post hoc test showed that the group with 6-10 years of teaching experience was significantly different from groups of 11-15 and 16-20 years of experience as illustrated in Table 6 below. However, this group did not differ significantly from the group of lecturers with 1-5 and more than 20 years of teaching experience.

Table 6. Tukey HSD post hoc test: Problem-based Learning

\begin{tabular}{|c|c|c|c|}
\hline & \multirow{2}{*}{} & \multicolumn{2}{c|}{ Subset for alpha $=\mathbf{. 0 5}$} \\
\cline { 3 - 4 } Teaching experience & $\mathbf{N}$ & $\mathbf{1}$ & $\mathbf{2}$ \\
\hline 16 - 20 years & 6 & 3.5000 & \\
$11-15$ years & 18 & 3.6667 & \\
1 - 5 years & 30 & 3.9667 & 3.9667 \\
$>$ 20 years & 16 & 4.1875 & 4.1875 \\
6 - 10 years & 20 & & 4.6000 \\
Sig. & & .214 & .290 \\
\hline
\end{tabular}

\subsection{Engineering program}

This sub-section deals with exploring the teaching approaches employed by the lecturers with regard to the engineering program they are teaching which are civil (CV), mechanical (ME), electrical and electronics (EE) and chemical (CE). The aim was to investigate whether the engineering program they were in has any influence on the teaching approaches they were using. In other words, the interest was to discover whether the engineering program they were teaching in differed over the teaching approaches they employed which may shed some light on the teaching approaches used in integrating soft skills with regard to engineering programs. The descriptive analysis of the assessment is followed by the ANOVA reports in which the test was performed to compare the results across programs. The mean score was analyzed and the frequency of employing teaching approaches like PBL, CL, TC, PjBL and POPBL were looked into. The summary of the results is presented in Table 7 below. 
Table 7. Mean scores for engineering programs with regard to teaching approaches

\begin{tabular}{|c|c|c|c|c|c|}
\hline $\begin{array}{l}\text { Teaching } \\
\text { approach }\end{array}$ & $\begin{array}{c}\text { Engineering } \\
\text { Program }\end{array}$ & $\mathbf{N}$ & Mean & $\begin{array}{l}\text { Std. } \\
\text { dev }\end{array}$ & Frequency \\
\hline PBL & $\begin{array}{c}\mathrm{CV} \\
\mathrm{ME} \\
\mathrm{EE} \\
\mathrm{CE} \\
\text { Total }\end{array}$ & $\begin{array}{l}21 \\
24 \\
24 \\
21 \\
90\end{array}$ & $\begin{array}{l}3.76 \\
3.83 \\
4.29 \\
4.33 \\
4.06\end{array}$ & $\begin{array}{l}.77 \\
1.13 \\
.69 \\
.79 \\
.89\end{array}$ & $\begin{array}{l}\text { High } \\
\text { High } \\
\text { High } \\
\text { High } \\
\text { High }\end{array}$ \\
\hline CL & $\begin{array}{c}\mathrm{CV} \\
\mathrm{ME} \\
\mathrm{EE} \\
\mathrm{CE} \\
\text { Total }\end{array}$ & $\begin{array}{l}21 \\
24 \\
24 \\
21 \\
90\end{array}$ & $\begin{array}{l}3.43 \\
3.87 \\
3.58 \\
4.00 \\
3.72\end{array}$ & $\begin{array}{l}1.07 \\
.99 \\
.97 \\
.95 \\
1.01\end{array}$ & $\begin{array}{c}\text { Average } \\
\text { High } \\
\text { Average } \\
\text { High } \\
\text { High }\end{array}$ \\
\hline TC & $\begin{array}{l}\mathrm{CV} \\
\mathrm{ME} \\
\mathrm{EE} \\
\mathrm{CE} \\
\text { Total }\end{array}$ & $\begin{array}{l}21 \\
24 \\
24 \\
21 \\
90\end{array}$ & $\begin{array}{l}3.67 \\
3.67 \\
3.87 \\
3.00 \\
3.57\end{array}$ & $\begin{array}{c}1.19 \\
1.09 \\
1.07 \\
.55 \\
1.05\end{array}$ & $\begin{array}{c}\text { High } \\
\text { High } \\
\text { High } \\
\text { Average } \\
\text { Average }\end{array}$ \\
\hline PjBL & $\begin{array}{c}\mathrm{CV} \\
\mathrm{ME} \\
\mathrm{EE} \\
\mathrm{CE} \\
\text { Total }\end{array}$ & $\begin{array}{l}21 \\
24 \\
24 \\
21 \\
90\end{array}$ & $\begin{array}{l}3.52 \\
3.75 \\
3.46 \\
4.19 \\
3.72\end{array}$ & $\begin{array}{l}.98 \\
.94 \\
1.18 \\
.87 \\
1.03\end{array}$ & $\begin{array}{c}\text { Average } \\
\text { High } \\
\text { Average } \\
\text { High } \\
\text { High }\end{array}$ \\
\hline POPBL & $\begin{array}{c}\mathrm{CV} \\
\mathrm{ME} \\
\mathrm{EE} \\
\mathrm{CE} \\
\text { Total }\end{array}$ & $\begin{array}{l}21 \\
24 \\
24 \\
21 \\
90\end{array}$ & \begin{tabular}{l|}
3.48 \\
3.63 \\
3.67 \\
4.24 \\
3.74
\end{tabular} & $\begin{array}{c}1.08 \\
1.28 \\
1.24 \\
.89 \\
1.16\end{array}$ & $\begin{array}{c}\text { Average } \\
\text { Average } \\
\text { High } \\
\text { High } \\
\text { High }\end{array}$ \\
\hline
\end{tabular}

With reference to Table 7, the analysis showed that the lecturers' means for PBL in relation to all the engineering programs ranged between 4.33 and 3.76, i.e. a high frequency. correspondingly. This has indicated that the usage of POPBL by the EE and CE lecturers in their teaching was highly frequent.

The analyses have also shown that lecturers from all four engineering programs seemed to employ all teaching approaches investigated in this study but by different degree of frequency. Interestingly, the lecturers in CE program obtained high frequency of usage for all four student-centred approaches addressed in this study which were PBL, CL, PjBL and POPBL with mean scores of 4.33, 4.00, 4.19 and 4.24, correspondingly. Nevertheless, for teacher-centred approach this group obtained lower means, 3.00 which signified average frequency. The group from CV, on the other hand, obtained average frequency on the use of student-centred approach like CL, PjBL and POPBL with mean score of 3.43, 3.52 and 3.48 respectively except for PBL which has slightly high mean score of 3.76 . In contrast, the $\mathrm{CV}$ group obtained slightly high mean score for teacher-centred approach with the score of 3.67. This indicated that the lecturers in CV program prefer the traditional teachercentred approach than student-centred approach. 
ANOVA test was conducted to explore the teaching methods employed by lecturers of different engineering programs in integrating soft skills in their teaching of technical courses, as measured by the questionnaire. Subjects were divided into four groups according to the engineering programs they were in (Civil, Mechanical, Electrical \& Electronics and Chemical). The analysis of the ANOVA test indicated that there was a statistically significant difference at the $\mathrm{p}<.05$ level in the scores for teacher-centered approach (TC) where $\mathrm{p}=0.032$. The other teaching approaches like PBL, CL, PjBL and POPBL obtained p-value of more than 0.05 which indicated no statistically significant difference in the scores. Table 8 shows the details of the results.

Table 8. General mean scores, standard deviation and p-value of respondents' teaching approach based on engineering programs using one-way ANOVA

\begin{tabular}{|c|c|c|c|c|c|}
\hline $\begin{array}{l}\text { Teaching } \\
\text { approach }\end{array}$ & Program & Mean & $\mathbf{N}$ & Std. dev & p-value \\
\hline PBL & $\begin{array}{c}\mathrm{CV} \\
\mathrm{ME} \\
\mathrm{EE} \\
\mathrm{CE} \\
\text { Total }\end{array}$ & $\begin{array}{l}3.76 \\
3.83 \\
4.29 \\
4.33 \\
4.06\end{array}$ & $\begin{array}{l}21 \\
24 \\
24 \\
21 \\
90\end{array}$ & $\begin{array}{c}.77 \\
1.13 \\
.69 \\
.79 \\
.89\end{array}$ & .055 \\
\hline CL & $\begin{array}{c}\mathrm{CV} \\
\mathrm{ME} \\
\mathrm{EE} \\
\mathrm{CE} \\
\text { Total }\end{array}$ & $\begin{array}{l}3.43 \\
3.87 \\
3.58 \\
4.00 \\
3.72\end{array}$ & $\begin{array}{l}21 \\
24 \\
24 \\
21 \\
90\end{array}$ & $\begin{array}{c}1.07 \\
.99 \\
.97 \\
.95 \\
1.01\end{array}$ & .223 \\
\hline TC & $\begin{array}{c}\mathrm{CV} \\
\mathrm{ME} \\
\mathrm{EE} \\
\mathrm{CE} \\
\text { Total }\end{array}$ & $\begin{array}{l}3.67 \\
3.67 \\
3.87 \\
3.00 \\
3.57\end{array}$ & $\begin{array}{l}21 \\
24 \\
24 \\
21 \\
90\end{array}$ & $\begin{array}{c}1.19 \\
1.09 \\
1.07 \\
.55 \\
1.05\end{array}$ & $.032 *$ \\
\hline $\mathrm{PjBL}$ & $\begin{array}{c}\mathrm{CV} \\
\mathrm{ME} \\
\mathrm{EE} \\
\mathrm{CE} \\
\text { Total }\end{array}$ & $\begin{array}{l}3.52 \\
3.75 \\
3.46 \\
4.19 \\
3.72\end{array}$ & $\begin{array}{l}21 \\
24 \\
24 \\
21 \\
90\end{array}$ & $\begin{array}{c}.98 \\
.94 \\
1.18 \\
.87 \\
1.03\end{array}$ & .078 \\
\hline POPBL & $\begin{array}{c}\text { CV } \\
\mathrm{ME} \\
\mathrm{EE} \\
\mathrm{CE} \\
\text { Total }\end{array}$ & $\begin{array}{l}3.48 \\
3.63 \\
3.67 \\
4.24 \\
3.74\end{array}$ & $\begin{array}{l}21 \\
24 \\
24 \\
21 \\
90\end{array}$ & $\begin{array}{c}1.08 \\
1.28 \\
1.24 \\
.89 \\
1.16\end{array}$ & .149 \\
\hline
\end{tabular}

In examining the teaching approaches employed by the lecturers to integrate soft skills in their teaching of technical courses, it can be summarized that first, the descriptive analysis have shown that all lecturers always use PBL as their teaching approach while the least approach being used was teacher-centered teaching approach. Second, the t-test indicates that there was no statistically significant difference in the approaches employed by the lecturers with industry experience (prior to becoming full time lecturers at this university) and those without industry experience. Similar patterns appeared in relation to the comparison by years of teaching experience, although with much bigger differences in the 
significantly positive ratings for PBL,PjBL, CL and POPBLin lecturers with 6-10 years of teaching experience. This group highly employed the approaches as compared to the other groups. Although these significant differences did not represent a big contrast, they were significantly different within the higher range of the frequency in utilizing the approaches. The patterns were also similar in the comparison by engineering program, with the lecturers from Chemical engineering (CE) program showing the most frequently usage of the student-centered approaches, the PBL, PjBL, CL and POPBL approaches. These approaches are effective in integrating soft skills in the teaching and learning process.

\section{Discussion}

Problem-based learning (PBL) is an inductive learning, team-based approach that focuses on developing thinking and learning skills in students. It utilizes real world problems, not hypothetical case studies with neat, convergent outcomes. In PBL students learn how to learn in a systematic way. This approach places particular emphasis on learning through questioning, self-directed learning, and also learning with their peers. Several studies have also revealed that PBL could help enhance the soft skills ability of students. As a result, students develop communication skills, critical thinking skills and problem solving abilities as well as team working skills. Also, this approach could help students to pave their ways to enhancing their personal development, increasing their level of self-confidence and empowering the students to be active learners, excel in team working as well as able to accept challenges (Aleem \& Jamaludin, 2007; Garcia \& Garza, 2015; Othman et al., 2017). The findings of this study have also revealed the same result. The lecturers indicated that PBL was used to integrate critical thinking and problem solving skills as well as communication skills. However, team work skills were also integrated indirectly because in PBL students are required to work in a team.

Analysis of the questionnaire survey reveals that the lecturers preferred to use the student-centred approach namely the Problem-based Learning (PBL), Project-based learning (PjBL), Cooperative Learning (CL) and Project Oriented Problem-based Learning (POPBL), more than the Teacher-Centred (TCA) approach. The results also show that the preference stayed constant in relation to the lecturers' experience with the industry, years of teaching experience and the engineering program they are in. Both groups with and without industry experience had the same patterns of preferences with more preference to PBL approach and least preference to Teacher-centred approach. Thus, this illustrates that the lecturers at this University prefer to employ student-centred approach which lead to producing students with better soft skills like critical thinking. This is further supported by Nygaard and Holtham (2008), who argue that a shift from a traditional paradigm with syllabus-driven didactic teaching to a learning-centred paradigm in higher education benefits student learning and facilitates students' self-development of higher order thinking skills and transferable competencies.

It is also worth noting that the lecturers with industry experience embarked into the teaching line without prior pedagogical experience. They were hired based on their industry experience which the University believes that could impart knowledge to the students through their hands-on experience in the industry. It is also one of the ways to bridge the gap between academic and industry. This study found that the lecturers with industry experience employ similar teaching methods as the ones without industry experience. Thus, this illustrates that the University has taken a profound approach by hiring people from the industry as academic staff. No doubt that knowledge on pedagogy is important for educators to possess but they could gain the knowledge by attending trainings on teaching and learning after they have entered the teaching world. A combination of their industry 
experience and pedagogical knowledge could make them better lecturers because they know the needs of both academic and industry.

Similar patterns appeared in relations to the comparison by years of teaching experience, although with much bigger differences in the significantly positive ratings for PBL, PjBL, $\mathrm{CL}$ and POPBL in lecturers with 6-10 years of teaching experience. This group highly employed the approaches as compared to the groups of 1-5, 11-15, 16-20 and more than 20 years of teaching experience. The study reveals that lecturers with more teaching experience employ more of the teacher-centred approach as compared to the less experience. Although these significant differences did not represent a big contrast, they were significantly different within the higher range of the frequency in utilizing the approaches. This may be because the lecturers with less than 10 years of teaching experience are more open to new approaches since they are still at the learning stage. The lecturers with more teaching experience may be more complacent with their regular approach.

\section{Conclusion}

Problem-Based Learning is a problem-centered teaching method with exciting potential in engineering education for motivating and enhancing student learning. Implementation of PBL in engineering education has the potential to bridge the gap between theory and practice. PBL also was adopted by many engineering programs as an approach to help students learn the skills required by the employers and to address many of the concerns that engineering graduates are lacking in of soft skills. In acknowledging the potential of PBL to develop the engineering students' soft skills ability, most of the lecturers do use this approach in their teaching but the frequency slightly differs based on their teaching and working experience.

\section{References}

Aleem, S.A. \& Jamaludin, M.Z. (2007). Problem-based learning (PBL) in an engineering course from students perspective. Proceedings of the Regional Conference on Engineering Education, Johor Bahru, 3-5 December 2007.

Beagon, U. \& Niall, D. (2015). Using problem-based learning to develop graduate attributes in first year engineering students. Proceedings of $43^{\text {rd }}$ Annual SEFI Conference, Orlean, France, June 29 - July 2, 2015.

Hamidah, S., Yuriani, S., \& Palupi. (2015). Integrated problem-based learning for improvement soft skill and high order thinking of vocational students. Proceedings of International Conference on Innovation and Vocational Education 2015,

Hazadiah, M. D, Marzita, P., Sidhu, G., \& Nor Aziah, A. (2008). Reengineering teaching and learning in higher education in the development of human capitol: The Malaysia initiatives. In C. Nygaard and C. Holtham (eds) Understanding learning-centred higher education. Denmark: Copenhagen Business School Press.

Khairiyah, M. Y., Syed Ahmad Helmi, S. H. and Zaidatun, T. (2007). A problem-based learning $(P B L)$ model for engineering and technical courses. Proceeding for Regional Conference of Engineering Education, Johor Bahru, Malaysia, 3-5 December, 2007. 
Landell, K. (1997). Management by menu. London: Wiley \& Sons Inc.

Nygaard, C., \& Holtham, C. (2008). The need for learning-centred higher education. In C.Nygaard \& Holthan, C. (ED.), Understanding learning-centred higher education (pp. 1129). Copenhagen, Denmark: Copenhagen Business School Press.

Othman, H., Mat Daud, K. A., Ewon, U., Mohd Salleh, B., Omar, N. H., Abd Baser, J., Ismail, M. E \& Sulaiman, A. (2017). Engineering students: Enhancing employability skills through PBL. IOP Conference Series: Materials Science and Engineering 203012024 